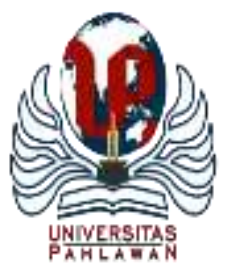

Edukatif : Jurnal Ilmu Pendidikan Volume 3 Nomor 4 Tahun 2021 Halm 1953 - 1961

EDUKATIF: JURNAL ILMU PENDIDIKAN

Research \& Learning in Education

https://edukatif.org/index.php/edukatif/index

\title{
Pengaruh Kecerdasan Emosional dan Kemandirian Belajar terhadap Keterampilan Berbicara Siswa di Sekolah Dasar
}

\author{
Titin Wijayanti $^{1 凶}$, Suhartono ${ }^{2}$, Juhana $^{3}$ \\ Universitas Terbuka, Indonesia ${ }^{1,3}$ \\ Universitas Sebelas Maret, Indonesia ${ }^{2}$ \\ E-mail : twijayanti49@ gmail.com ${ }^{1}$, $\underline{\text { suhartono@ fkip.uns.ac.id }}^{2}$, juhana@ecampus.ut.ac.id $^{3}$
}

\begin{abstract}
Abstrak
Keterampilan berbicara merupakan kemampuan yang sangat penting dalam berkomunikasi secara lisan. Penelitian ini bertujuan untuk mengetahui pengaruh kecerdasan emosional dan kemandirian belajar terhadap keterampilan berpikir kritis pada siswa kelas VI sekolah dasar se-Kecamatan Sruweng dengan pendekatan kuantitatif dengan jenis penelitian regresi, pengambilan sample menggunakan simple random sampling, dan pengumpulan data dengan angket dan tes perbuatan. Teknik analisis data dengan uji asumsi klasik dan uji regresi ganda dengan menggunakan SPSS 25. Berdasarkan analisis data diperoleh kesimpulan sebagai berikut: (1) Ada pengaruh kecerdasan emosional terhadap keterampilan berbicara sebesar 26,3\% dengan nilai Sig = 0,000. (2) Ada pengaruh kemandirian belajar terhadap keterampilan berbicara sebesar 16,4\% dengan nilai Sig $=0,000$. (3) Ada pengaruh kecerdasan emosional dan kemandirian belajar terhadap keterampilan berbicara sebesar $35 \%$. Hal ini membuktikan bahwa ada pengaruh antara kecerdasan emosional, kemandirian belajar, dan keterampilan berbicara.
\end{abstract}

Kata Kunci: keterampilan berbicara; kecerdasan emosional; kemandirian belajar.

\section{Abstract}

Speaking skill is a very important ability in verbal communication. This study aims to determine the effect of emotional intelligence and learning independence on critical thinking skills in grade VI elementary school students in Sruweng District with a quantitative approach with regression research type, sampling using simple random sampling, and data collection using questionnaires and action tests. The data analysis technique used classical assumption test and multiple regression test using SPSS 25. Based on the data analysis, the following conclusions were obtained: (1) There was an influence of emotional intelligence on speaking skills of $26.3 \%$ with a Sig value of 0.000. (2) There is an effect of learning independence on speaking skills of 16.4\% with a value of Sig $=0.000$. (3) There is an influence of emotional intelligence and learning independence on speaking skills by $35 \%$. This proves that there is an influence between emotional intelligence, independent learning, and speaking skills.

Keywords: speaking skills; emotional intelligence; learning independence.

Copyright (c) 2021 Titin Wijayanti, Suhartono, Juhana

$\triangle$ Corresponding author

Email : twijayanti49@gmail.com

DOI : https://doi.org/10.31004/edukatif.v3i4.1048 
1954 Pengaruh Kecerdasan Emosional dan Kemandirian Belajar terhadap Keterampilan Berbicara Siswa di Sekolah Dasar-Titin Wijayanti, Suhartono, Juhana

DOI: https://doi.org/10.31004/edukatif.v3i4.1048

\section{PENDAHULUAN}

Komunikasi merupakan penggerak kehidupan karena melalui komunikasi makhluk hidup dapat menjalin interaksi. Terampil berbahasa sangat dibutuhkan makhluk sosial untuk berkomunikasi. Muthmainah, Fahrurrozi, dan Herlina (2019) menyatakan berbicara adalah mengungkapkan secara lisan gagasan, pikiran, dan perasaan dari pembicara kepada orang yang mendengarkan. Keterampilan berbicara adalah kompetensi seseorang untuk melisankan gagasan serta mendengarkan dengan bijaksana ketika menerima informasi (Hayani, 2019). Jadi keterampilan berbicara sangat penting bagi siswa.

Siswa diharapkan terampil mengungkapkan pikiran, gagasan, ide, dan perasaan menggunakan bahasa yang santun. Kenyataan di lapangan keterampilan berbicara masih rendah dibandingkan dengan keterampilan menyimak, membaca, dan menulis. Hal ini berdasarkan nilai ujian praktik pada siswa kelas VI. Hasil obesrvasi di Korwilcambidik Kecamatan Sruweng, diketahui bahwa siswa kelas VI memperoleh rerata nilai pada ujian praktik berbicara hasilnya rendah dibandingkan kompetensi yang lain. Rerata kompetensi menyimak 82 , berbicara sebesar 74 , membaca sebesar 80 , dan menuis sebesar 83 . Masalah yang dihadapi siswa dalam berbicara gugup, malu, dan volume suara rendah saat berpidato.

Aspek-aspek keterampilan berbicara menurut Nawawi, Qura, dan Rahmayanti (2017) yaitu ketepatan pengucapan, intonasi, pemilihan kata, sistematis, dalam berbicara mempunyai sikap tenang, pandangan diarahkan ke lawan bicara, kesediaan menghargai pendapat orang lain. Dengan demikian ada beberapa faktor yang mempengaruhi hal tersebut yaitu faktor internal dan eksternal. Faktor internal antara lain meliputi kepribadian, cara berpikir, dan intelektualitas (Hazran, 2013).

Intelektualitas atau kecerdasan merupakan kemampuan dalam memahami dan menyadari terhadap apa yang dialami baik perkataan, pikiran, dan perbuatan. Pada dasarnya manusia dibekali dengan kecerdasan intelektual, kecerdasan emosional, dan kecerdasan spiritual. Kecerdasan merupakan kemampuan seseorang untuk memecahkan masalah yang dihadapi. Tridhonanto (2009) menyatakan kecerdasan emosional pada anak diantaranya mampu memahami diri sendiri baik kelebihan maupun kekurangan sebagai pendukung dalam menemukan jati dirinya melalui identitas diri. Hariwijaya (2010) menyatakan kecerdasan emosional merupakan kemampuan memahami dan bertindak sederhana dalam berhubungan dengan orang lain. Purnaningtyas dan Suharto (2010) menyatakan kecerdasan emosional adalah penggunaan emosi untuk mengendalikan situasi membedakan perasaan dalam diri pada individu lainnya, serta mempertahankan fokus dan memahami apa yang dianggap penting.

Komponen-komponen kecerdasan emosional menurut Purnaningtyas dan Suharto (2010) yaitu kesadaran diri, pengaturan diri, motivasi, empati, dan keterampilan sosial Jadi kecerdasan emosional merupakan kemampuan merasakan, memahami, dan secara efektif mengaplikasikan kekuatan, kecerdasan emosi sebagai sumber energi manusia, informasi, hubungan,pengaruh, dan keterampilan yang berhubungan dengan pembinaan sosial, lingkungan, dan kemampuan memotivasi diri sendiri, serta mengelola emosi dengan baik yang mencakup komponen-komponen kesadaran diri, pengaturan diri, motivasi, empati, dan keterampilan sosial.

Keterampilan berbicara juga erat kaitannya dengan kemandirian belajar siswa. Kemandirian merupakan kebebasan seseorang untuk menentukan masa depannya tanpa bergantung orang lain (Somawati, 2016). Definisi lain menyebutkan bahwa menyatakan kemandirian adalah keadaan kesempurnaan dan keutuhan kedua unsur budi dan akal dalam kesatuan pribadi (Somawati, 2016). Dapat disimpulkan kemandirian yaitu kemampuan seseorang untuk mengambil keputusan dan menentukan arah hidupnya tanpa tergantung orang lain serta mampu bertanggung jawab.

Pengertian belajar menurut Supriyani (2016) merupakan tahapan perubahan secara tingkah laku individu yang relatif menetap sebagai hasil pengalaman dan interaksi dengan lingkungan yang melibatkan proses kognitif. Pernyataan Warsono dan Hariyanto (2012) belajar pada hakikatnya merupakan hasil dari 
1955 Pengaruh Kecerdasan Emosional dan Kemandirian Belajar terhadap Keterampilan Berbicara Siswa di Sekolah Dasar-Titin Wijayanti, Suhartono, Juhana

DOI: https://doi.org/10.31004/edukatif.v3i4.1048

proses interaksi antara individu dengan lingkungan sekitar. Jadi belajar merupakan suatu proses peningkatan kemampuan kognitif, afektif, dan psikomotor sesuai tingkat kecerdasan masing-masing individu dan dipengaruhi oleh lingkungan, belajar juga merupakan sesuatu yang berkenaan dengan aspek-aspek psikis dan fisik yang relatif bersifat konsultan. Dapat ditarik kesimpulan kemandirian belajar yaitu suatu perubahan dalam diri seseorang meliputi kognitif, afektif, psikomotor yang merupakan hasil pengalaman serta latihan tanpa bergantung pada orang lain, mempunyai kebebasan membuat keputusan, penialaian tentang sesuatu, bebas berpendapat sesuai dengan apa yang dipikirkan serta bertanggung jawab.

Komponen-komponen kemandirian belajar yaitu adanya sifat ingin tahu yang besar, mempunyai keinginan untuk maju, mempunyai keinginan untuk berbuat lebih baik dan memperbaiki kesalahan, selalu belajar lebih awal sehingga percaya diri dalam belajar tercapai, melakukan sesuatu dengan tekun (Somawati, 2016).

Hasil penelitian terdahulu yang dilakukan Masruroh, Sundari, dan Wulan (2016) tentang pengaruh kecerdasan emosional terhadap keterampilan berbicara siswa sekolah dasar menunjukkan bahwa keterampilan berbicara sangat penting dalam kehidupan sosial dibuktikan dengan penelitian di SDN Sempu 1 Kota Serang dengan hasil indeks korelasi sebesar 0,96678 dan $r$ berada antara $(0,08-0,100)$. Dalam penelitian tersebut kecerdasan emosional berpengaruh terhadap keterampilan berbicara.

Pendapat lain diungkapkan oleh Putri (2013) tentang pengaruh kecerdasan emosional dan kepercayaan diri terhadap prestasi belajar. Penelitian ini di laksanakan di Magelang dengan hasil menunjukkan jika $\mathrm{F}$ hitung $(51,024)>\mathrm{F}$ tabel $(3,097698)$ dan secara parsial untuk kecerdasan emosional $t$ hitung $(9,210)>t$ tabel $(1,986674)$ dan $t$ hitung $(2,199)>t$ tabel $(1,986674)$ untuk kepercayaan diri. Penelitian tersebut menunjukkan persamaan dalam variabel bebas dengan penelitian yang sedang dilakukan.

Berdasarkan uraian yang telah dikemukakan sebelumnya dapat diketahui bahwa tujuan penelitian ini untuk menganalisis pengaruh kecerdasan emosionaldan kemandirian belajar terhadap keterampilan berbicara pada siswa kelas VI SD se-Kecamatan Sruweng.

\section{METODE PENELITIAN}

Penelitian ini adalah penelitian kuantitaif yang dianalisis dengan uji linier berganda. Ada dua variabel bebas (independent variable) yaitu kecerdasan emosional $\left(\mathrm{X}_{1}\right)$ dan kemandirian belajar $\left(\mathrm{X}_{2}\right)$ dalam penelitian ini. Sedangkan variabel terikat adalah keterampilan berbicara (Y). Populasi dalam penelitian ini adalah seluruh siswa Kelas VI SD Negeri di Kecamatan Sruweng Kabupaten Kebumen dengan jumlah 533 siswa. Sedangkan sampel penelitian diperoleh dengan cara simple random sampling yaitu sampel sejumlah 7 siswa diambil secara acak dari 33 SD Negeri dengan jumlah subyek penelitian 231 siswa yang dilaksanakan pada bulan agustus s.d Oktober 2020.

Berikut desain penelitian yang menunjukkan hubungan antar variabel penelitian yang digambarkan pada Gambar 1. berikut:

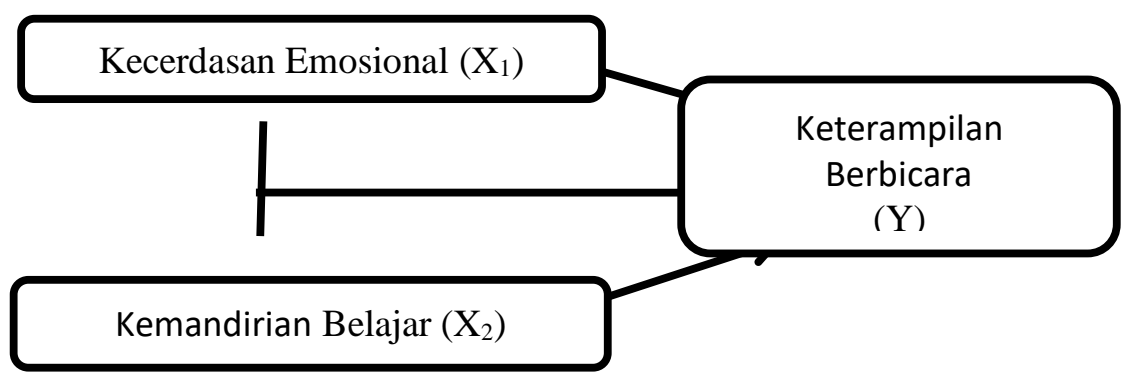

Gambar 1: Desain Penelitian

Edukatif : Jurnal Ilmu Pendidikan Vol 3 No 4 Tahun 2021 p-ISSN 2656-8063 e-ISSN 2656-8071 
Instrumen yang digunakan dalam penelitian ini adalah instrumen tes (tes perbuatan keterampilan berbicara) dan angket (kecerdasan emosional dan kemandirian belajar) yang disusun berdasarkan kisi-kisi instrumen yang telah disusun sebelumnya. Angket dikembangkan dengan skala Likert dengan menyajikan empat alternatif jawaban yang bersifat positif. Semakin tinggi kecerdasan emosional dan kemandirian belajar, sedangkan semakin rendah dinyatakan dengan skor 1. Untuk tiap-tiap item soal dengan perincian sebagai berikut.

1) Selalu (SL) dengan nilai 4

2) Sering (SR) dengan nilai 3

3) Jarang Sekali (JS) dengan nilai 2

4) Tidak Pernah (TP) dengan nilai 1

Teknik analisis pengujian instrumen peneltilian dilakukan pula dengan uji validitas dan uji reliabilitas. Instrumen diujicobakan setelah dianalisis isi oleh dua orang tim ahli judgement expert sebelum digunakan yang selanjutnya dihitung menggunakan indeks V dari Aiken. Instrumen kemudian diujicobakan pada 2 SD Negeri dengan 32 responden.

Instrumen keterampilan berbicara untuk pengambilan data menggunakan tes perbuatan berpidato dan lembar penilaian meliputi 6 aspek yaitu pengucapan, intonasi, pilihan kata, sistematika berbicara, sikap berbicara, kesantunan berbahasa. Kecerdasan emosional dan kemandirian belajar diukur dengan skor komulatif yang menunjukkan adanya kecerdasan emosional dan kemandirian belajar dalam diri siswa yang diperoleh melalui angket setelah siswa menjawab butir-butir pernyataan yang tersaji dalam instrumen angket berbentuk skala Likert. Instrumen kecerdasan emosional terdiri dari 24 butir pernyataan dan kemandirian belajar 24 butir pernyataan. Reliabilitas tes keterampilan berbicara adalah 0,814. Reliabilitas angket kecerdasan emosional sebesar 0,969. Sedangkan reliabilitas kemandirian belajar diperoleh sebesar 0, 956 .

Teknik analisis data terdiri dari analisis deskriptif dan analisis statistik. Secara deskriptif, data dijabarkan berdasarkan rata-rata (mean), nilai tengah (median), nilai yang sering muncul (modus), standar uji linear regresi berganda melalui uji $\mathrm{t}$ dan uji $\mathrm{F}$ yang sebelumnya terlebih dahulu dilakukan uji asumsi klasik seperti uji normalitas, uji linieritas, uji multikolinieritas, uji heterokedastositas. Uji t dilakukan untuk menunjukkan seberapa jauh pengaruh yang nyata secara parsial antara kecerdasan emosional terhadap keterampilan berbicara maupun pengaruh antara kemandirian belajar terhadap keterampilan berbicara siswa. Sedangkan uji $\mathrm{F}$ dilakukan untuk mengetahui apakah kecerdasan emosional dan kemandirian belajar berpengaruh secara bersama-sama terhadap keterampilan berbicara siswa. Proses perhitungan data penelitian dilakukan dengan menggunakan SPSS 25.

Berdasarkan pemaparan yang telah diuraikan sebelumnya dengan faktor yang diduga memiliki pengaruh terhadap keterampilan berbicara siswa kelas VI SD, maka hipotesis yang diuji diuraikan sebagai berikut :

H1: Ada pengaruh kecerdasan emosional terhadap keterampilan berbicara pada siswa kelas VI SD seKecamatan Sruweng.

H2: Ada pengaruh kemandirian belajar terhadap keterampilan berbicara pada siswa kelas VI SD seKecamatan Sruweng.

H3: Ada pengaruh kecerdasan emosional dan kemandirian belajar terhadap keterampilan berbicara siswa kelas VI SD se-Kecamatan Sruweng

\section{HASIL DAN PEMBAHASAN PENELITIAN}

Jumlah sampel dalam penelitian adalah 33 SD negeri dan setiap SD hanya diambil 7 sampel dengan jumlah siswa 231 siswa. Secara deskriptif variabel terikat (Y) adalah keterampilan berbicara. Data keterampilan berbicara diperoleh melalui tes perbuatan dengan 6 aspek. Selanjutnya yang menjadi variabel 
1957 Pengaruh Kecerdasan Emosional dan Kemandirian Belajar terhadap Keterampilan Berbicara Siswa di Sekolah Dasar-Titin Wijayanti, Suhartono, Juhana

DOI: https://doi.org/10.31004/edukatif.v3i4.1048

bebas $\left(\mathrm{X}_{1}\right)$ adalah kecerdasan emosional. Selain itu, variabel bebas lainnya $\left(\mathrm{X}_{2}\right)$ adalah kemandirian belajar yang diperoleh dari angket dengan 24 butir pernyataan adapun ringkasan deskripsi hasil penelitian ditampilkan dalam Tabel 1 berikut :

Tabel 1 Ringkasan Hasil Perhitungan Statistik Deskriptif

\begin{tabular}{lccc}
\hline \multicolumn{1}{c}{ Data Statistik } & Keterampilan Berbicara & Kecerdasan Emosional & Kemandirian Belajar \\
\hline Mean & 26.34 & 75.79 & 73.23 \\
\hline Median & 26.00 & 76.00 & 73.00 \\
\hline Mode & 25 & 79 & 73 \\
\hline Std. Deviation & 2.187 & 7.556 & 4.459 \\
\hline Variance & 4.783 & 57.090 & 19.884 \\
\hline Range & 10 & 36 & 22 \\
\hline Minimum & 20 & 54 & 64 \\
\hline Maximum & 30 & 90 & 86 \\
\hline Sum & 6085 & 17507 & 16917 \\
\hline
\end{tabular}

Sumber : Data primer yang diolah

Secara statistik data hasil penelitian terlebih dahulu dilakukan uji asumsi klasik atau uji prasyarat analis data yaitu uji normalitas, uji linieritas, uji multikolinieritas, dan uji heterokedastisitas. Uji normalitas data dilakukan untuk mengetahui apakah data setiap kelompok sampel berdistribusi normal dengan KolmogorofSmirnov melalui perolehan angka probabilitas atau Asymp. Sig. (2. Tailed) dengan kriteria signifikansi $5 \%$ $(0,05)$ yang menunjukkan data berdistribusi normal jika signifikansi data $\geq 0,05$, sedangkan signifikansi data $<0,05$ menunjukkan data tidak berdistribusi normal.

Tabel 2 Ringkasan Hasil Perhitungan Uji Normalitas Data

\begin{tabular}{lrr}
\hline & & Unstandardized Residual \\
\hline $\mathrm{N}$ & & \multicolumn{1}{c}{231} \\
\hline Normal Parameters $^{\mathrm{a}}$ & .0000000 & .0000000 \\
\hline & 1.76293269 & 9.30991555 \\
\hline Most & .109 & .065 \\
\hline Extreme & .073 & .039 \\
\hline Differences & -.109 & -.065 \\
\hline Kolmogorov-Smirnov Z & & 1.656 \\
\hline Asymp. Sig. (2-tailed) & & .080 \\
\hline
\end{tabular}

Berdasarkan tabel 2 di atas bahwa seluruh sampel berdistribusi normal angka probabilitas atau Asymp. Sig. (2-tailed $) \geq 0,05$, dengan demikian seluruh sampel dalam penelitian ini berasal dari populasi yang berdistribusi normal.

Uji asumsi klasik berikutnya adalah uji linieritas untuk mengetahui hubungan antar variabel linier atau tidak dari hasil $F_{\text {hitung }}$ Deviation From Linearity. Kriteria pengujiannya jika Fhitung $<$ Ftabel, maka kedua variabel berpola linier. Jika Fhitung > Ftabel, maka kedua variabel memiliki pola yang tidak linier. Hasil uji linieritas antara kecerdasan emosional dengan keterampilan berbicara maka dapat diketahui nilai Sig. deviation from linearity sebesar 0,060 > 0,050, maka dapat disimpulkan bahwa Terdapat hubungan yang linear antara variabel bebas (kecerdasan emosional siswa) dengan variabel terikat (keterampilan berbicara siswa). Hasil uji linearitas dari kemandirian belajar, maka dapat diketahui nilai Sig. deviation from linearity sebesar 0,447>0,05, maka dapat disimpulkan bahwa terdapat hubungan yang linear antara variabel bebas (kemandirian belajar siswa) dengan variabel terikat (keterampilan berbicara siswa). 
1958 Pengaruh Kecerdasan Emosional dan Kemandirian Belajar terhadap Keterampilan Berbicara Siswa di Sekolah Dasar-Titin Wijayanti, Suhartono, Juhana

DOI: https://doi.org/10.31004/edukatif.v3i4.1048

Uji multikolinieritas dilakukan untuk menunjukkan adanya hubungan korelasi dan linier antara variabel kecerdasan emosioanl dan kemandirian belajar terhadap variabel keterampilan berbicara berdasarkan nilai Variance Inflation Faktor (VIF) dan nilai tolerance dari masing-masing variabel bebas terhadap variabel terikat. Hasil perhitungan nilai (VIF) adalah 1,055 dengan niali toleransi 0,947. Dengan demikian diperoleh kesimpulan bahwa dalam model regresi tidak terjadi multikolinieritas.

Uji asumsi klasik yang terakhir adalah uji heteroskedastisitas yang akan menunjukkan varian variabel tidak sama untuk semua pengamatan. yang diperoleh pada kolom Unstrandardized Residual pada hasil SPSS. Model regresi dengan nilai Sig. lebih besar dari taraf signifikansi (sig. > 0,05) menunjukkan tidak adanya heteroskedastisitas. Hasil perhtungan diperoleh nilai Sig. Kecerdasan emosional 0,107 dan motivasi belajar

0, 477. Hasil tersebut menunjukkan bahwa model regresi ini terbebas dari heteroskedastisitas.

Setelah seluruh rangkaian uji asumsi klasik terpenuhi, data hasil penelitian kemudian diuji hipotesisnya melalui uji $\mathrm{t}$ dan uji $\mathrm{F}$. Uji t dilakukan untuk membuktikan pengaruh kecerdasan emosional terhadap keterampilan berbicara dan membuktikan pengaruh kemandirian belajar terhadap keterampilan berbicara. Sedangkan uji $\mathrm{F}$ dilakukan untuk membuktikan pengaruh kecerdasan emosional dan kemandirian belajar secara bersama-sama terhadap keterampilan berbicara.

\section{Pengaruh Kecerdasan Emosional terhadap Keterampilan Berbicara}

Berdasarkan hasil uji t dengan kriteria pengujian hipotesis diterima jika apabila nilai signifikasi $\leq 0,05$ maka hipotesis diterima yang berarti ada pengaruh antara variabel bebas terhadap variabel terikat. Sedangkan hipotesis ditolak apabila nilai signifikansi $>0,05$. Hasil perhitungan diperoleh Sig. t $0,00<\alpha(0,05)$ dengan $r$ sebesar 0,513 menunjukkan hubungan kecerdasan emosional dengan keterampilan berbicara yaitu cukup positif dengan korelasi koefisien sebesar 0,263 menunjukkan kontribusi yang disumbangkan X1 kepada Y yaitu $26,3 \%$.

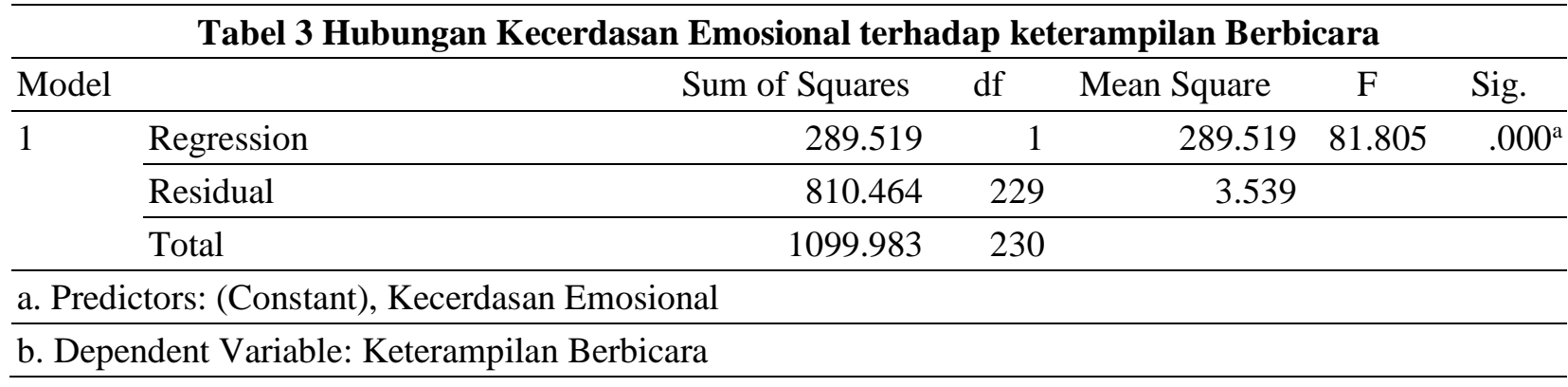

Perbandingan Fhitung dan Ftabel serta Sig dan $\alpha$ : Fhitung $=81,805>$ Ftabel $=3,89$, maka Ho ditolak dan Ha diterima. Sig $=0,000<\alpha=0,050$, maka Ho ditolak dan Ha diterima.

Hasil perhitungan menunjukkan bahwa ada pengaruh kecerdasan emosional terhadap keterampilan berbicara. Dengan demikian, maka hasil temuan penelitian ini sejalan dengan teorinya. Seseorang dengan kemampuan kecerdasan emosional tinggi akan mampu mengenal dirinya sendiri, menggunakan informasi untuk membimbing pikiran dan tindakan sehingga berpengaruh dengan suasana perasaannya dalam melakukan kegiatan (Ayuandia et al., 2017). Sulistyawati (2018) menyatakan "emotional intelegence affects speaking skills" kecerdasan emosional berpengaruh terhadap keterampilan berbicara. Siswa yang memiliki kecerdasan emosional tinggi akan memiliki keterampilan berbicara yang baik.

Hasil penelitian ini juga mendukung penelitian terdahulu yang dilakukan oleh Masruroh, Sundari, dan Wulan (2016) yang menyatakan bahwa secara signifikan kecerdasan emosional berpengaruh terhadap keterampilan berbicara siswa sekolah dasar. Melalui pembelajaran yang memeprtimbangkan kecerdasan 
1959 Pengaruh Kecerdasan Emosional dan Kemandirian Belajar terhadap Keterampilan Berbicara Siswa di Sekolah Dasar-Titin Wijayanti, Suhartono, Juhana

DOI: https://doi.org/10.31004/edukatif.v3i4.1048

emosional, keterampilan berbicara dapatdikembangkan secara optimal sehingga siswa menjadi terampil dalam berbicara.

\section{Pengaruh Kemandirian Belajar terhadap Keterampilan Berbicara}

Berdasarkan hasil uji t dengan kriteria pengujian hipotesis diterima jika apabila nilai signifikasi $\leq 0,05$ maka hipotesis diterima yang berarti ada pengaruh antara variabel bebas terhadap variabel terikat. Sedangkan hipotesis ditolak apabila nilai signifikansi $>0,05$. Hasil perhitungan diperoleh Sig. t $0,00<\alpha(0,05)$ dengan $r$ sebesar 0,405 menunjukkan hubungan kemandirian belajar dengan keterampilan berbicara yaitu cukup positif dengan korelasi koefisien sebesar 0,164 menunjukkan kontribusi yang disumbangkan X2 kepada Y yaitu 16,4 $\%$.

Tabel 4 Hubungan Kemandirian Belajar terhadap Keterampilan Berbicara

\begin{tabular}{llrrrrr}
\hline Model & \multicolumn{1}{l}{ Sum of Squares } & df & Mean Square & F & \multicolumn{1}{l}{ Sig. } \\
\hline \multirow{2}{*}{1} & Regression & 180.089 & 1 & 180.089 & 44.832 & $.000^{\text {a }}$ \\
\cline { 2 - 7 } & Residual & 919.894 & 229 & 4.017 & & \\
\cline { 2 - 7 } & Total & 1099.983 & 230 & & & \\
\hline
\end{tabular}

Perbandingann Fhitung dan Ftabel serta Sig dan $\alpha$ : Fhitung $=44,832>$ Ftabel $=3,89$, maka Ho ditolak dan Ha diterima. Sig $=0,000<\alpha=0,05$, maka Ho ditolak dan Ha diterima.

Hasil perhitungan menunjukkan bahwa ada pengaruh kemandirian belajar terhadap keterampilana berbicara. Dengan demikian, maka hasil temuan penelitian ini sesuai dengan teori yang menyatakan bahwa kemandirian belajar bertumpu pada prinsip bahwa individu belajar hanya akan sampai pada perolehan hasil belajar, mulai keterampilan, pengembangan nalar, pembentukan sikap sampai pada penemuan diri sendiri dalam proses belajar (Somawati, 2016). Selanjutnya juga menguatkan teorinya Supriyani (2016) menyatakan ciri-ciri kemandirian belajar adalah mampu mengambil inisiatif, mampu mengatasi masalah, penuh ketekunan, memperoleh kepuasan ketika belajar, dan mempunyai keinginan untuk mengerjakan sesuatu tanpa tergantung orang lain.

\section{Pengaruh Kecerdasan Emosional dan Kemandirian Belajar terhadap Keterampilan Berbicara}

Kecerdasan Emosional dan Kemandirian Belajar secara bersama-sama memiliki korelasi positif dengan Keterampilan Berbicara Siswa. Hal tesebut terbukti dari nilai $\mathrm{R}$ sebesar 0,592. Positif artinya searah, maksudnya semakin tinggi Kecerdasan Emosional dan Kemandirian Belajar, maka semakin tinggi Keterampilan Berbicara Siswa. Selanjutnya, untuk menguji apakah semua variabel independen $\left(\mathrm{X}_{1}\right.$ dan $\left.\mathrm{X}_{2}\right)$ secara bersama-sama memiliki pengaruh yang signifikan terhadap variabel dependen (Y), maka digunakan Uji F.

Tabel 5 Hubungan Kemandirian Belajar terhadap Keterampilan Berbicara

\begin{tabular}{lrrrrr}
\hline \multicolumn{1}{c}{ Model } & Sum of Squares & \multicolumn{1}{c}{ df } & Mean Square & F & \multicolumn{1}{c}{ Sig. } \\
\hline Regression & 385.158 & 2 & 192.579 & 61.425 & $.000^{\mathrm{a}}$ \\
\hline Residual & 714.824 & 228 & 3.135 & & \\
\hline Total & 1099.983 & 230 & & & \\
\hline
\end{tabular}

Berdasarkan hasil Uji F, diketahui bahwa Fhitung $=61,425>$ Ftabel $=3,89$, maka Ho ditolak dan Ha diterima. Selanjutnya, nilai Sig $=0,000<\alpha=0,050$, maka Ho ditolak dan Ha diterima. Dengan demikian, hipotesis ketiga yang dinyatakan "Kecerdasan Emosional dan Kemandirian Belajar secara bersama-sama 
1960 Pengaruh Kecerdasan Emosional dan Kemandirian Belajar terhadap Keterampilan Berbicara Siswa di Sekolah Dasar-Titin Wijayanti, Suhartono, Juhana

DOI: https://doi.org/10.31004/edukatif.v3i4.1048

memiliki pengaruh yang positif terhadap Keterampilan Berbicara Siswa Kelas VI Sekolah Dasar seKecamatan Sruweng" adalah terbukti kebenarannya. Adapun $\mathrm{R}^{2}$ (r square atau korelasi koefisien) sebesar 0,350 menunjukkan kontribusi yang disumbangkan $\mathrm{X}_{1}$ dan $\mathrm{X}_{2}$ secara bersama-sama kepada $\mathrm{Y}$ yaitu $35 \%$.

Dengan demikian, hasil temuan penelitian ini secara khusus sejalan dengan yang diungkapkan oleh Ayuandia (2017); Somawati (2016); Supriyani (2016); dan Sulistyawati (2018) sebagaimana telah dikemukakan di depan. Hal tesebut karena Kecerdasan Emosional dan Kemandirian Belajar secara bersamasama memang memiliki korelasi dan pengaruh yang positif terhadap Keterampilan Berbicara Siswa Kelas VI Sekolah Dasar se-Kecamatan Sruweng.

\section{KESIMPULAN}

Berdasarkan pemaparan hasil analisis yang telah dilakukan, diperoleh kesimpulan sebagai berikut: 1) ada pengaruh yang signifikan antara kecerdasan emosional terhadap keterampilan berbicara siswa kelas VI SD se-Kecamatan Sruweng. 2) Ada pengaruh yang signifikan antara kemandirian belajar terhadap keterampilan berbicara siswa kelas VI SD se-Kecamatan Sruweng. 3) Ada pengaruh yang signifikan antara kecerdasan emosional dan kemandirian belajar terhadap keterampilan berbicara siswa kelas VI SD se-Kecamatan Sruweng

\section{UCAPAN TERIMA KASIH}

Terima kasih saya ucapakan kepada keluarga, dosen pembimbing yang telah memberikan ilmu yang sangat bermanfaat demi penyelesaian TAPM ini, rekan-rekan mahasiswa Prodi Magister Pendidikan Dasar Universitas Terbuka, seluruh dosen dan staff UPBJJ UT Purwokerto yang telah membantu peneliti dalam menyelesaikan penelitian ini.

\section{DAFTAR PUSTAKA}

Ayuandia, N., Saparahayuningsih, S., \& Ardina, M. (2017). Meningkatkan Keterampilan Berbicara Melalui Metode Karyawisata Pada Anak Kelompok B Lab School Paud Unib Kota Bengkulu. Jurnal Ilmiah Potensia, 2(1), 33-38.

Hariwijaya. (2010). Kecerdasan. Universitas Terbuka.

Hayani, H. (2019). Peningkatan Keterampilan Berbicara Melalui Metode Bermain Peran Di Sekolah Dasar. Pedagogik Journal Of Islamic Elementary School, 2(2), 221-230.

Hazran, H. (2013). Kemampuan Berbicara Siswa Di Kelas Iii Sdn Nomor I Tulo Kecamatan Dolo Kabupaten Sigi. Jurnal Kreatif Online, 6(3).

Masruroh, I., Sundari, N., \& Wulan, N. S. (2016). Keterampilan Berbicara Siswa Sekolah Dasar Effect Of Emotional Intelligence To Speak Skills. Kalimaya, 4(2), 1-13.

Muthmainnah, Z. (2019). Pengaruh Penggunaan Media Audio Visual Terhadap Keterampilan Berbicara Pada Peserta Didik Kelas V Sekolah Dasar. Dinamika Bahasa Sekolah Dasar, 1(1), 1-12.

Nawawi, N., Qura, U., \& Rahmayanti, I. (2017). Keterampilan Berbicara Sebagai Suatu Keterampilan Berbahasa. Uhamka Press.

Purnaningtyas, A., \& Suharto, S. (2010). Pengaruh Kecerdasan Emosi Terhadap Prestasi Belajar Siswa Mata Pelajaran Seni Budaya Smp. Harmonia: Journal Of Arts Research And Education, 10(1).

Putri, F. S. (2013). Pengaruh Kecerdasan Emosional Dan Kepercayaan Diri Terhadap Prestasi Belajar Mata Pelajaran Akuntansi Kelas Xi Is Sma Negeri 3 Magelang. Universitas Negeri Semarang. 
1961 Pengaruh Kecerdasan Emosional dan Kemandirian Belajar terhadap Keterampilan Berbicara Siswa di Sekolah Dasar- Titin Wijayanti, Suhartono, Juhana

DOI: https://doi.org/10.31004/edukatif.v3i4.1048

Somawati, S. (2016). Pengaruh Kecemasan Dan Kemandirian Belajar Terhadap Kemampuan Komunikasi Matematika Siswa Sma Negeri Di Kecamatan Pasar Rebo. Research And Development Journal Of Education, 3(1), 35-51. Https://Doi.Org/10.30998/Rdje.V3i1.1470

Sulistyawati, M. E. S. (2018). The Effects Of Emotional Intelligence On Students' Speaking Skills. Edulangue, 1(1), 39-66.

Supriani, Y. (2016). Menumbuhkan Kemandirian Belajar Matematika Siswa Berbantuan Quipper School. Jipmat, 1(2).

Tridhonanto, A. (2009). Melejitkan Kecerdasan Emosi (Eq) Buah Hati. Elex Media Komputindo.

Warsono, H., \& Hariyanto, M. S. (2012). Pembelajaran Aktif Teori Dan Asesmen. Pt Remaja Rosdakarya. 